\title{
Beet sugar syrup and molasses as low-cost feedstock for the enzymatic production of fructo-oligosaccharides
}

\author{
Iraj GHAZI, Lucía FERNÁNDEZ-ARROJO, Aranzazu GOMEZ DE SEGURA\#, \\ Miguel ALCALDE, Francisco J. PLOU* and Antonio BALLESTEROS
}

Departamento de Biocatálisis, Instituto de Catálisis y Petroleoquímica, CSIC, Cantoblanco, 28049 Madrid, Spain.

* Corresponding autor: Francisco J. Plou, Departamento de Biocatálisis, Instituto de Catálisis y Petroleoquímica, CSIC, Cantoblanco, Marie Curie 2, 28049 Madrid, Spain. Fax: +34-91-5854760. E-mail: fplou@icp.csic.es. Internet: http://www.icp.csic.es/abg

\# Present address: Facultad de Veterinaria, Universidad Autónoma de Barcelona, Departamento de Ciencia Animal y de los Alimentos, Unidad de Nutrición Animal, 08193 Bellaterra, Barcelona, Spain

Running title: Fructo-oligosaccharides synthesis from syrup and molasses 


\section{$1 \quad$ ABSTRACT}

2 Sugar syrup and molasses from beet processing containing 620 and $570 \mathrm{mg} / \mathrm{ml}$ sucrose, 3 respectively, were assayed as low-cost and available substrates for the enzymatic synthesis 4 of fructo-oligosaccharides (FOS). A commercial pectinase (Pectinex Ultra SP-L, from 5 Aspergillus aculeatus) characterised by the presence of a transfructosylating activity, was

6 used as biocatalyst. The FOS production increased when lowering the initial $\mathrm{pH}$ value of 7 syrup (7.5) and molasses (8.9) to 5.5. Sugar syrup and molasses were diluted in order to 8 reduce substrate viscosity; interestingly, the percentage of FOS with regards to total sugars

9 remained almost constant, which indicated a high transferase to hydrolase ratio for this 10 enzyme. Kinetics of FOS production was analysed. Using approx. $10 U$ transfructosylating 11 activity per $\mathrm{g}$ sucrose, the FOS concentration reached a maximum of $388 \mathrm{mg} / \mathrm{ml}$ after $30 \mathrm{~h}$ 12 using syrup and $235 \mathrm{mg} / \mathrm{ml}$ in $65 \mathrm{~h}$ with molasses. These values corresponded to approx. $1356 \%$ and $49 \%(\mathrm{w} / \mathrm{w})$, respectively, of the total amount of carbohydrates in the mixture. The enzyme was also covalently immobilised on an epoxy-activated polymethacrylate-based polymer (Sepabeads ${ }^{\circledR}$ EC-EP5). We found that immobilised Pectinex Ultra SP-L can be efficiently applied to the synthesis of FOS using syrup and molasses as substrates.

Keywords: $\beta$-Fructofuranosidase, Fructosyltransferase, Transglycosidase, Sucrose, Prebiotics, Polymethacrylate, Pectinex Ultra SP-L, Animal feed. 


\section{1. INTRODUCTION}

Fructo-oligosaccharides (FOS) of the inulin-type constitute one of the most established groups of prebiotics in the world (1). Addition of such molecules to food products may help to prevent illness, control calcium balance and contribute to the reduction of antibiotic consumption $(2,3)$.

FOS of the inulin-type are fructose oligomers with a terminal glucose group, in which 2-4 fructosyl moieties are linked via $\beta(1 \rightarrow 2)$-glycosidic bonds (4). Commercial FOS are mainly composed of 1 -kestose $\left(\mathrm{GF}_{2}\right)$, nystose $\left(\mathrm{GF}_{3}\right)$ and $1^{\mathrm{F}}$-fructosylnystose $\left(\mathrm{GF}_{4}\right)$. The properties of other types of FOS, such as those of the levan-type (5) and the neo-FOS (6), are very promising, but they are not commercially available yet.

FOS are industrially produced through fructosyl transfer from pure sucrose using a fungal enzyme (7). FOS-synthesising enzymes are present in many higher plants (asparagus, chicory, onion, Jerusalem artichoke, etc.) and microorganisms, especially fungi (Aureobasidium pullulans, Aspergillus niger, Aspergillus oryzae, etc.) (4;8-10). FOSproducing enzymes are assigned as hydrolases ( $\beta$-fructofuranosidases, EC 3.2.1.26) or fructosyltransferases (transfructosidases, EC 2.4.1.9). The maximal FOS production for a particular enzyme depends on the relative rate of transfructosylation and hydrolysis (11).

In addition to their use in human food products, the administration of FOS to the diets of some animals results in improvement in feed efficiency and a reduction of diarrhoea and smell in feces (12). In order to extend the use of FOS as animal feed additives, it is necessary to minimise production costs. Beet sugar syrup and molasses are cheap and available sources of sucrose, and are adequate feedstock for FOS production of animal-feed grade.

Pectinex Ultra SP-L is a commercial enzyme preparation from Aspergillus aculeatus used in the food industry for fruit juice processing to reduce viscosity. It contains different pectinolytic and cellulolytic enzymes (e.g. endo-poly-galacturonase, endo-pectinylase and 
1 pectin esterase) (13). Interestingly, Pectinex Ultra SP-L also contains a transfructosylating 2 activity $(14,15)$.

In this work, we have assayed Pectinex Ultra SP-L, soluble or immobilised on a epoxy-activated polymethacrylate (Sepabeads EC-EP), for transformation of beet syrup and 5 molasses into FOS.

6 


\section{2. EXPERIMENTAL PROCEDURES}

2 Materials

3 The beet sugar syrup and molasses were kindly donated by Azucarera Ebro (Valladolid, 4 Spain). Pectinex Ultra SP-L (batch No. KRN05401) was kindly donated by Novozymes A/S. 5 Sepabeads EC-EP5 (batch No. E407P094) was kindly provided by Resindion S.R.L.

6 (Mitsubishi Chemical Corporation, Milan, Italy). Glucose and dinitrosalicylic acid were from

7 Sigma. Sucrose and fructose were purchased from Merck. 1-Kestose and nystose were from

$8 \mathrm{TCl}$ Europe (Zwijndrecht, Belgium). $1^{\mathrm{F}}$-Fructosylnystose was from Megazyme (County

9 Wicklow, Ireland). All other reagents and solvents were of the highest available purity and 10 used as purchased.

\section{Standard activity microassay}

The enzymatic activity towards sucrose was measured following the initial rate of reducing sugars production by the dinitrosalicylic acid (DNS) method. The spectrophotometric assay was adapted to a 96-well microplate scale as described (16). One unit (U) of activity was conditions.

\section{Immobilisation of fructosyltransferase}

Pectinex Ultra SP-L $(20 \mathrm{ml})$ and Sepabeads EC-EP5 $(8 \mathrm{~g})$ were mixed and incubated for 24

$\mathrm{h}$ at room temperature with roller shaking. The ratio protein/support was approx. $45 \mathrm{mg}$ protein per gram of carrier. The biocatalyst was then filtered, washed $(3 \times 30 \mathrm{ml})$ with $50 \mathrm{mM}$ sodium acetate buffer ( $\mathrm{pH} 5.6)$, dried under vacuum and stored at $4^{\circ} \mathrm{C}$.

\section{Batch production of fructo-oligosaccharides}

Soluble or immobilised Pectinex Ultra SP-L was added to diluted beet sugar syrup and molasses, previously filtered through a glass microfibre filter. Total reaction volume was $5 \mathrm{ml}$. 
1 The biocatalyst was added to a final activity in the mixture of $1 \mathrm{U} / \mathrm{ml}$ or $5 \mathrm{U} / \mathrm{ml}$ (determined by

2 the standard DNS microassay). The mixtures were incubated at $60{ }^{\circ} \mathrm{C}$ in an orbital shaker

3 (Stuart Scientific) at $200 \mathrm{rpm}$. At different times, $40 \mu \mathrm{l}$ aliquots were extracted from the

4 reaction mixture, diluted with $160 \mu \mathrm{l}$ water and incubated $10 \mathrm{~min}$ at $90{ }^{\circ} \mathrm{C}$ to inactivate the

5 enzyme. Samples were centrifuged $5 \mathrm{~min}$ at $6000 \mathrm{rpm}$ using an eppendorf with a $0.45 \mu \mathrm{m}$

6 Durapore ${ }^{\circledR}$ membrane (Millipore), and analysed by HPLC.

7

$8 \quad$ HPLC analysis

9 The concentration of the different products was analysed by HPLC with a quaternary pump

10 (Delta 600, Waters) coupled to a Lichrosorb-NH2 column (250 x $4.6 \mathrm{~mm})$ (Merck). The

11 mobile phase was acetonitrile:water $(75: 25 \mathrm{v} / \mathrm{v})$, conditioned with helium, and used at a flow

12 rate of $0.7 \mathrm{ml} / \mathrm{min}$. The column temperature was kept constant at $25^{\circ} \mathrm{C}$. A differential

13 refractometric detector (model 9040, Varian) was used and set to a constant temperature of

$1430 \stackrel{\circ}{ } \mathrm{C}$. The data obtained were analysed using the Millennium Software. 


\section{3. RESULTS AND DISCUSSION}

2

\section{Composition of sugar syrup and molasses}

Sugar syrup is the sugar juice obtained after beet juice evaporation, from which sucrose is crystallised. Molasses is the main by-product of the sugar industry. Both sources are notably less expensive than pure sucrose for production of FOS. The use of molasses for FOS synthesis has only been explored by Shin et al. in cultures of Aureobasidium pullulans cells (9) whereas, to our knowledge, the sugar syrup has not been assayed as an alternative substrate in this process.

Sugar syrup and molasses are mixtures of sucrose and other carbohydrates. Molasses has also more unidentified components and some particulate materials (esp. carbonates). Table 1 shows the specifications of beet syrup and molasses that have been used in this study. Sugar syrup and molasses were viscous solutions containing 620 and 570 $\mathrm{mg} / \mathrm{ml}$ sucrose and $0.6 \%$ and $5.6 \%(\mathrm{w} / \mathrm{w})$ of betaine (trimethyl glycine), respectively. The weight distribution of carbohydrates in syrup was $74.7 \%$ sucrose, $13.6 \% 1$-kestose, $7.5 \%$ glucose, $3.5 \%$ nystose and $0.7 \%$ fructose; molasses contained $95.7 \%$ sucrose, $2.9 \%$ glucose and $1.4 \%$ of other carbohydrates. It is noteworthy the presence of a considerable amount of FOS $(17.1 \%)$ in the syrup. The 1-kestose content depends on the origin of the raw material and the type of technology adopted in beet processing $(17,18)$, and may cause shape and kinetic modifications of the final sucrose crystals. On the other hand, kestoses are becoming increasingly important due to their properties as prebiotic compounds. Other trisaccharides such as raffinose and neokestose were also present, especially in sugar syrup, but at a lower concentration $(<0.2 \% \mathrm{w} / \mathrm{w})$ compared with 1 -kestose.

\section{Effect of $\mathrm{pH}$ and substrate concentration on FOS production}

The presence of a fructosyl-transfer activity in commercial Pectinex Ultra SP-L from Novozymes A/S (used in juice clarification) was first reported by Hang and Woodams (14). Using Pectinex Ultra SP-L, we found that fructose was formed in a very small scale 
1 compared with that of glucose, which indicated that this activity was better defined by a

2 transfructosidase than a $\beta$-fructofuranosidase (16). Optimum $\mathrm{pH}$ and temperature for

3 production of fructooligosaccharides from sucrose using Pectinex Ultra SP-L were reported

45.5 and $60{ }^{\circ} \mathrm{C}$, respectively (19). Recently we have purified the enzyme responsible for this

5 transfructosidase activity (data not shown).

6 The initial $\mathrm{pH}$ of the sugar syrup and molasses was 7.5 and 8.9 , respectively. We

7 observed that FOS production from syrup increased from 30.6 to $36.4 \%$ when moving from

8 the starting $\mathrm{pH}(7.5)$ to $\mathrm{pH} 5.5$ (by the addition of glacial acetic acid), whereas for molasses

9 an increment from 3.5 to $14.8 \%$ was observed when lowering $\mathrm{pH}$ from 8.9 to 5.5 .

In order to reduce the viscosity of the feedstock, which may cause technological difficulties, several dilutions from syrup and molasses were prepared by adding distilled water to the substrate and adjusting $\mathrm{pH}$ to 5.5 . This allowed us to investigate the effect of substrate concentration on FOS production.

The synthesis of fructooligosaccharides from sucrose is a kinetically controlled reaction that involves a fructosyl-enzyme intermediate. The nucleophiles $\mathrm{H}_{2} \mathrm{O}$ and sucrose compete for the fructosyl-enzyme intermediate. When $\mathrm{H}_{2} \mathrm{O}$ is the nucleophile, the enzyme acts as a hydrolase (releasing glucose and fructose). When sucrose is the nucleophile, the enzyme acts as a transfructosidase. The first condensation product (1-kestose) can also be hydrolysed by the enzyme. The reaction time must be carefully controlled to stop the process when the maximum yield of condensation products is achieved. The maximum yield of FOS depends on two parameters: the concentration of sucrose and the intrinsic transferase/hydrolase ratio of the enzyme. In order to improve the yield of transfructosylating products, a high sucrose concentration must be used to increase the ratio $k_{3} \cdot[$ Sucrose $] / k_{2} \cdot\left[\mathrm{H}_{2} \mathrm{O}\right](20)$.

Different diluted solutions of syrup and molasses containing Pectinex Ultra SP-L (5 $\mathrm{U} / \mathrm{ml}$ ) were incubated at $60{ }^{\circ} \mathrm{C}$ for $24 \mathrm{~h}$, and FOS content analysed. Table 2 summarises the initial sucrose concentration, as well as the sucrose conversion and FOS production in $24 \mathrm{~h}$. 
1 It is noteworthy that the FOS percentage (referred to the total amount of carbohydrates)

2 maintained a value close to $53-57 \%(\mathrm{w} / \mathrm{w})$ for syrup and $41-46 \%(\mathrm{w} / \mathrm{w})$ for molasses, which

3 confirmed that the transferase/hydrolase ratio for this enzyme must be considerably high. As

4 expected, the maximum FOS production (460 $\mathrm{mg} / \mathrm{ml}$ for syrup and $245 \mathrm{mg} / \mathrm{ml}$ for molasses)

5 was obtained without dilution. In contrast, $1^{\mathrm{F}}$-fructosylnystose (GF4) production increased

6 with substrate dilutions (up to 12-fold with syrup and 42-fold with molasses, Table 2). In fact,

7 at lower sucrose concentrations the formation of high polymerisation degree products is

8 favoured, as there exists more competition between sucrose and reaction products to accept

9 a fructosyl unit.

\section{Batch production of fructooligosaccharides}

We analysed the kinetics of FOS batch production of fructooligosaccharides (FOS) from sugar syrup and molasses. To have an efficient mixing, dilutions (1:1.2) from syrup and molasses were utilised. Fig. 1 shows the progress of the process and Fig. 2 represents the percentage and concentration $(\mathrm{mg} / \mathrm{ml})$ of total FOS. In the case of syrup, the FOS concentration reached a maximum value of $388 \mathrm{mg} / \mathrm{ml}$ after $30 \mathrm{~h}(228 \mathrm{mg} / \mathrm{ml}$ 1-kestose, 149

\section{Immobilisation of fructosyltransferase on Sepabeads EC-EP5}

Sepabeads EC are polymethacrylate-based carriers for enzyme immobilisation. The series Sepabeads EC-EP is epoxy-activated, with a high reactive group density. The porosity of these materials is very suitable to obtain biocatalysts with a high volumetric activity. The 
1 chemistry for attachment enzyme/support is straightforward. Compared with other epoxy

acrylic polymers, Sepabeads EC-EP carriers possess high mechano-osmotic stability, low compressibility and high resistance to microbial attack. Furthermore, the raw materials applied for the production of these supports are included in the EU list of resins allowed for the processing of foodstuffs (21).

Fructosyltransferase enzyme in Pectinex Ultra SP-L was immobilised on Sepabeads EC-EP5. Immobilisation was carried out by mixing the Pectinex and the polymer, without any buffer or $\mathrm{pH}$ adjustment (16). The protein concentration in commercial preparation of the enzyme was $17.8 \mathrm{mg} / \mathrm{ml}$. The activity towards sucrose, using the DNS assay, was $321 \mathrm{U} / \mathrm{ml}$. Protein content of the immobilised biocatalyst was $36 \mathrm{mg} / \mathrm{g}$ of support and its activity 21.0 U/g biocatalyst.

Fructosyltransferase immobilised on Sepabeads FP-EC5 was utilised for FOS production. Pure sucrose $(630 \mathrm{mg} / \mathrm{ml})$, sugar syrup and molasses were comparatively used as substrates. Fig. 3 shows the FOS production and FOS percentage -referred to total carbohydrates in the mixture-, with the different starting materials. It is interesting to note that these values correlated well with those obtained with the soluble enzyme. The highest percentage of FOS in the final mixture $(61 \%)$ was found with pure sucrose. This value is very close to that we obtained with the related support Sepabeads EC-EP3 (16), and comparable to the reported with other immobilised transfructosidases (22). The FOS percentage determined with sugar syrup and molasses (53\% and $37.5 \%$ ) can be considered very satisfactory. It is interesting to point out that, in terms of FOS production, the highest value was found with sugar syrup (440 mg/ml) compared with $385 \mathrm{mg} / \mathrm{ml}$ and $215 \mathrm{mg} / \mathrm{ml}$ obtained with pure sucrose and molasses, respectively. This is a simple consequence of the presence of FOS in the starting syrup.

As syrup and molasses are coloured materials and the FOS specifications for human nutrition are very restrictive in this subject, the FOS obtained by the methods described in this work could be easily employed for animal feed. In the recent past years, some relevant changes have been introduced in the nutrition of farmed animals, in order to cover the needs 
1 of essential nutrients and/or to optimise feed utilisation. Examples include the administration

2 of immuno-stimulants or natural substances having an anti-bacterial effect. Prebiotics are

3 being already employed to control pathogenic bacteria, reduce faecal odour, and enhance

4 growth performance. Research to date indicates positive effects of prebiotics on health status

5 and performance of companion animals, livestock, and poultry (23-25). The process for FOS

6 synthesis described here is inexpensive, simple, efficient and, employing the immobilised

7 biocatalyst, easy to scale-up to different reactor configurations.

8

\section{ACKNOWLEDGEMENTS}

10 We are very grateful to Azucarera Ebro (Valladolid, Spain) for supplying beet sugar syrup 11 and molasses. We thank Drs. Moreno Daminati and Paolo Caimi (Resindion S.R.L., Milan, 12 Italy) for providing us Sepabeads EC polymers and for technical help. We are grateful to 13 Ramiro Martínez (Novozymes A/S, Spain) for providing us with Pectinex Ultra SP-L. 


\section{REFERENCES}

1. Bornet, F. R. J.; Brouns, F.; Tashiro, Y.; Duvillier, V. Nutritional aspects of short-chain fructooligosaccharides: natural occurrence, chemistry, physiology and health implications. Dig. Liver Dis. 2002, 34, S111-S120.

2. Gibson,G.R.; Ottaway,R.A. Prebiotics: New developments in functional foods, Ed. Chandos Publishing: Oxford, 2000.

3. Tuohy, K. M.; Rouzaud, G. C. M.; Bruck, W. M.; Gibson, G. R. Modulation of the human gut microflora towards improved health using prebiotics - Assessment of efficacy. Curr. Pharm. Design 2005, 11, 75-90.

4. Antosova, M.; Polakovic, M. Fructosyltransferases: The enzymes catalyzing production of fructooligosaccharides. Chem. Pap.-Chem. Zvesti 2001, 55, 350-358.

5. Marx, S. P.; Winkler, S.; Hartmeier, W. Metabolization of beta-(2,6)-linked fructoseoligosaccharides by different bifidobacteria. FEMS Microbiol. Lett. 2000, 182, 163-169.

6. Grizard, D.; Barthomeuf, C. Enzymatic synthesis and structure determination of NEOFOS. Food Biotechnol. 1999, 13, 93-105.

7. Hirayama, M.; Sumi, N.; Hidaka, H. Purification and properties of a fructooligosaccharide-producing beta-fructofuranosidase from Aspergillus niger ATCC20611. Agric. Biol. Chem. 1989, 53, 667-673.

8. Sangeetha, P. T.; Ramesh, M. N.; Prapulla, S. G. Fructooligosaccharide production using fructosyl transferase obtained from recycling culture of Aspergillus oryzae CFR 202. Process Biochem. 2005, 40, 1085-1088. 
9. Shin, H. T.; Baig, S. Y.; Lee, S. W.; Suh, D. S.; Kwon, S. T.; Lim, Y. B.; Lee, J. H. Production of fructo-oligosaccharides from molasses by Aureobasidium pullulans cells. Bioresour. Technol. 2004, 93, 59-62.

10. Fernandez, R. C.; Maresma, B. G.; Juarez, A.; Martinez, J. Production of fructooligosaccharides by beta-fructofuranosidase from Aspergillus sp. $27 \mathrm{H}$. J. Chem. Technol. Biotechnol. 2004, 79, 268-272.

11. Nguyen, Q. D.; Rezessy-Szabo, J. M.; Bhat, M. K.; Hoschke, A. Purification and some properties of beta-fructofuranosidase from Aspergillus niger IMI303386. Process Biochem. 2005, 40, 2461-2466.

12. Spiegel, J. E.; Rose, R.; Karabell, P.; Frankos, V. H.; Schmitt, D. F. Safety and benefits of fructooligosaccharides as food ingredients. Food Technol. 1994, 48, 85-89.

13. Okai, A. A. E.; Gierschner, K. Size and charge properties of the pectic and cellulolytic enzymes in a commercial enzyme preparation Z. Lebensm. Unters. Forsch. 1991, 192, 244-248.

14. Hang, Y. D.; Woodams, E. E. Fructosyltransferase activity of commercial enzyme preparations used in fruit juice processing. Biotechnol. Lett. 1995, 17, 741-745.

15. Tanriseven, A.; Gokmen, F. Novel method for the production of a mixture containing fructooligosaccharides and isomaltooligosaccharides. Biotechnol. Tech. 1999, 13, $207-$ 210.

16. Ghazi, I.; Gómez de Segura, A.; Fernández-Arrojo, L.; Alcalde, M.; Yates, M.; RojasCervantes, M. L.; Plou, F. J.; Ballesteros, A. Immobilisation of fructosyltransferase from Aspergillus aculeatus on epoxy-activated Sepabeads EC for the synthesis of fructooligosaccarides. J. Mol. Catal. B: Enz. 2005, 35, 19-27. 
17. Vaccari, G.; Lodi, G.; Tamburini, E.; Bernardi, T.; Tosi, S. Detection of oligosaccharides in sugar products using planar chromatography. Food Chem. 2001, 74, 99-110.

18. Vaccari, G.; Mantovani, G.; Sgualdino, G.; Tamburini, E.; Aquilano, D. Fructooligosaccharides and sucrose crystal growth morphology- I. Experimental growth habits. Zuckerindustrie 1999, 124, 34-39.

19. Tanriseven, A.; Aslan, Y. Immobilization of Pectinex Ultra SP-L to produce fructooligosaccharides. Enz. Microb. Technol. 2005, 36, 550-554.

20. Buchholz, K.; Kasche, V.; Bornscheuer, U. T. Biocatalysts and Enzyme Technology, Wiley-VCH Verlag: Weinheim, 2005.

21. Resolution $\mathrm{AP}(97) 1$, On ion exchange and adsorbent resins used in the processing of foodstuffs (adopted by the EU Committee of Ministers on September 30, 1997).

22. Lee, W. C.; Chiang, C. J.; Tsai, P. Y. Kinetic modeling of fructo-oligosaccharide production catalyzed by immobilized beta-fructofuranosidase. Ind. Eng. Chem. Res. 1999, 38, 2564-2570.

23. Brambilla, G.; De Filippis, S. Trends in animal feed composition and the possible consequences on residue tests. Anal. Chim. Acta 2005, 529, 7-13.

24. Mosenthin, R.; Bauer, E. The potential use of prebiotics in pig nutrition. Asian-Aus. J. Anim. Sci. 2000, 13, 315-325.

25. Flickinger, E. A.; Fahey, G. C. Pet food and feed applications of inulin, oligofructose and other oligosaccharides. Br. J. Nutr. 2002, 87, S297-S300.

This research was supported by the Spanish Education and Science Ministry (Project BIO2004-03773-C04-01). We thank the Spanish AECI, Gobierno Vasco and Instituto Danone for research fellowships. 
Table 1. Some specifications of the beet sugar syrup and molasses used in this work.

\begin{tabular}{lcc}
\hline & Sugar syrup & Molasses \\
\hline Brix units $^{\mathrm{a}}$ & 69.3 & 75.1 \\
$\mathrm{pH}$ & 7.5 & 8.9 \\
Density $(\mathrm{g} / \mathrm{ml})$ & 1.30 & 1.40 \\
${\text { Sucrose }(\%)^{\mathrm{b}}}^{\mathrm{b}}$ & 47.5 & 40.7 \\
${\text { [Sucrose] }(\mathrm{mg} / \mathrm{ml})^{\mathrm{c}}}$ & 620 & 570 \\
${\text { Betaine }(\%)^{\mathrm{d}}}$ & 0.6 & 5.6 \\
\hline
\end{tabular}

a Grams of dry matter per $100 \mathrm{~g}$ of sample, provided by the manufacturer.

${ }^{b}$ Grams of sucrose per $100 \mathrm{~g}$ of sample, determined by HPLC.

${ }^{c}$ Determined by HPLC.

${ }^{d}$ Grams of betaine per $100 \mathrm{~g}$ of sample, provided by the manufacturer. 


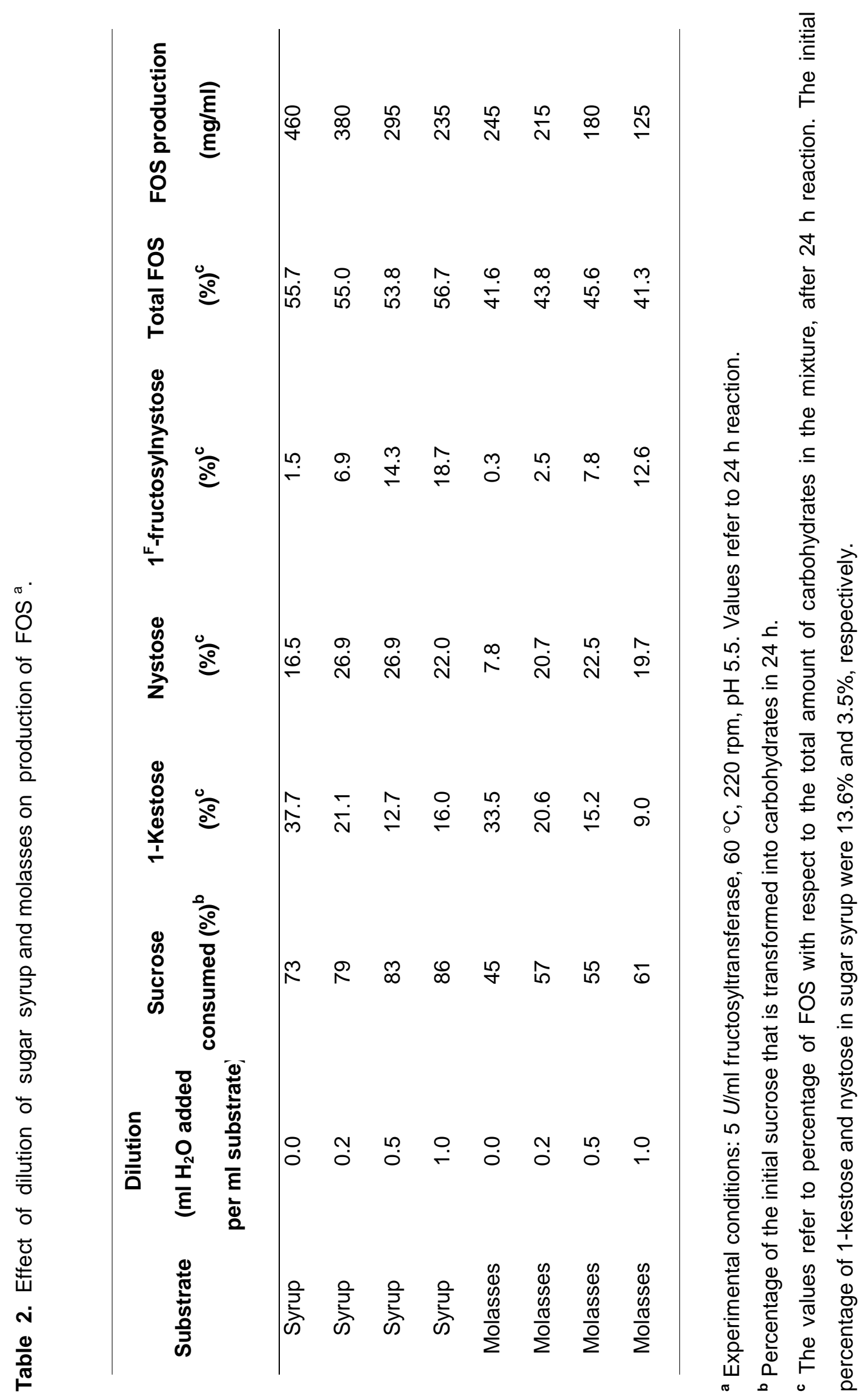




\section{Figure Legends}

Fig. 1. Time dependency of FOS batch production from (A) beet sugar syrup and (B) molasses, catalysed by soluble Pectinex Ultra SP-L. Experimental conditions: pH 5.5, 5.0 $\mathrm{U} / \mathrm{ml}$ (standard DNS assay), $60^{\circ} \mathrm{C}$. The substrate was diluted by adding $0.2 \mathrm{ml} \mathrm{H}_{2} \mathrm{O}$ per $\mathrm{ml}$.

Fig. 2. (A) Kinetics of FOS production and (B) percentage of FOS referred to the total amount of carbohydrates using sugar syrup $(\circ)$ and molasses $(\bullet)$ Experimental conditions: $\mathrm{pH} 5.5,5.0 \mathrm{U} / \mathrm{ml}$ (standard DNS assay), $60^{\circ} \mathrm{C}$. The substrate was diluted by adding $0.2 \mathrm{ml}$ $\mathrm{H}_{2} \mathrm{O}$ per ml.

Fig. 3. (A) FOS production and (B) percentage of FOS referred to the total amount of carbohydrates using sucrose $(630 \mathrm{mg} / \mathrm{ml})$, beet sugar syrup and molasses, catalysed by immobilised Pectinex Ultra SP-L in Sepabeads EC-EP5. Experimental conditions: $1.0 \mathrm{U} / \mathrm{ml}$ (standard DNS assay), $\mathrm{pH} 5.5,60{ }^{\circ} \mathrm{C}$. The initial percentage of FOS in sugar syrup was $17.1 \%(142 \mathrm{mg} / \mathrm{ml})$-indicated by a black bar-. 
Fig. 1
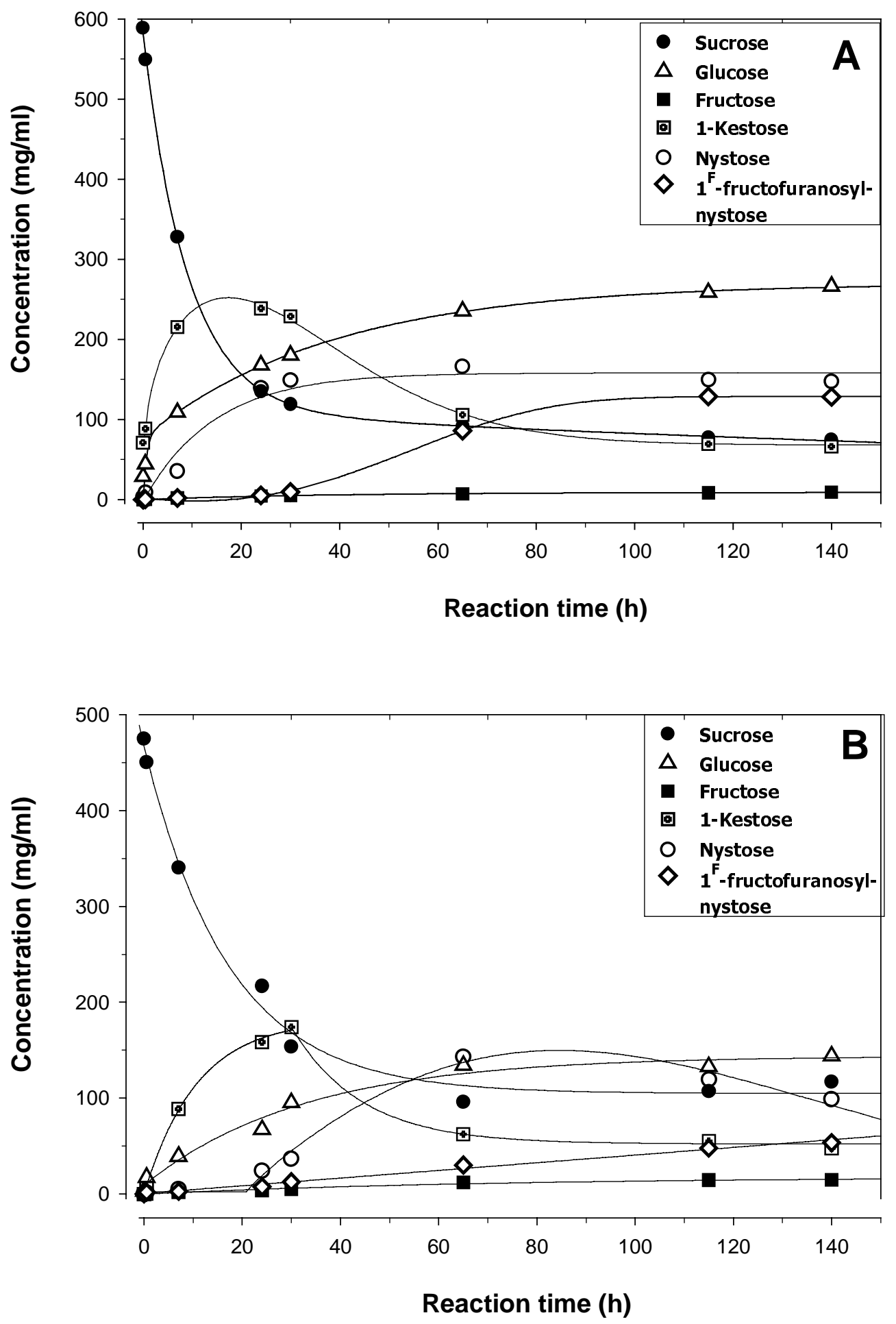
ํํำ

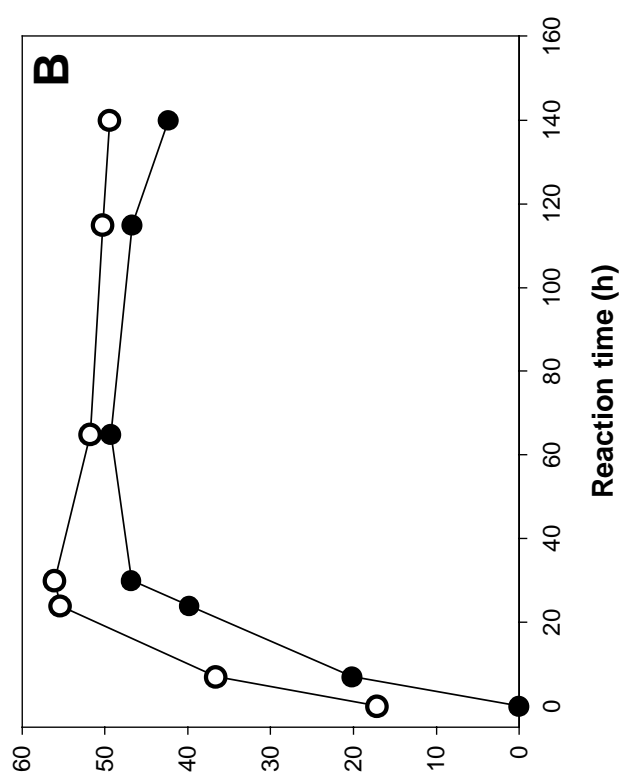

(\%) SOJ

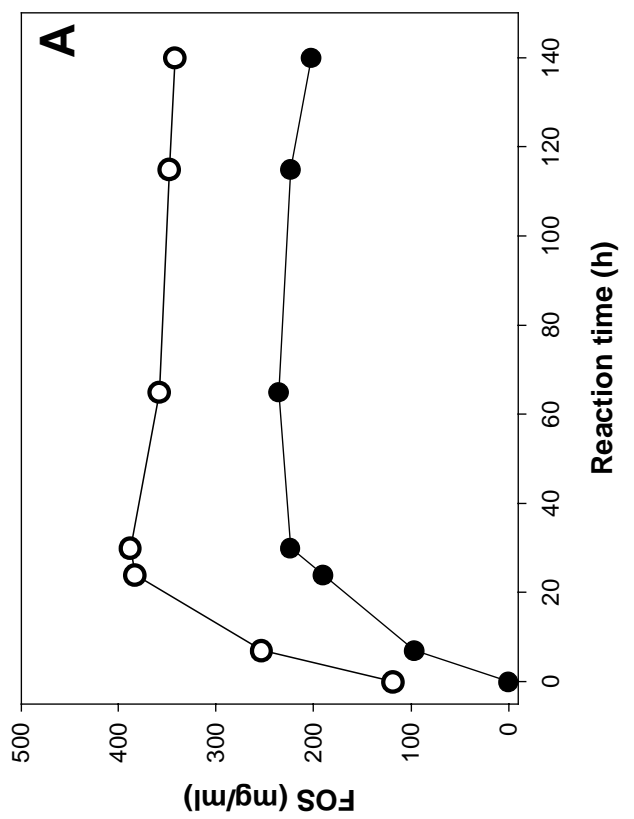


옴

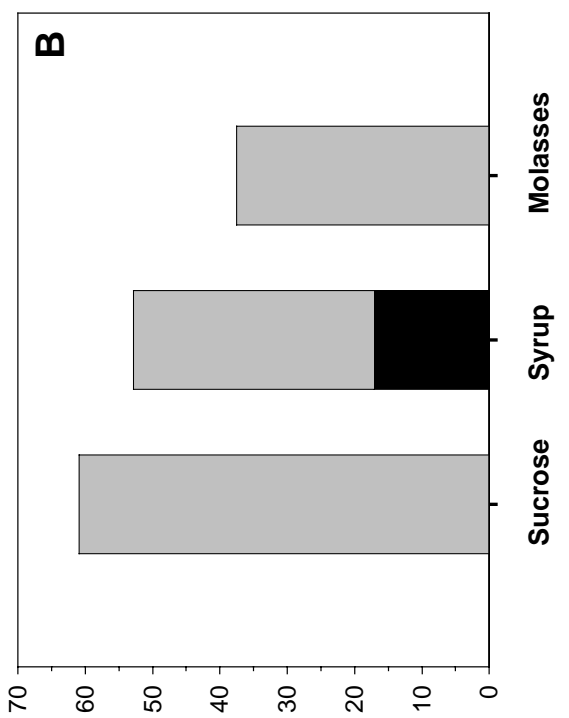

(\%) SOJ

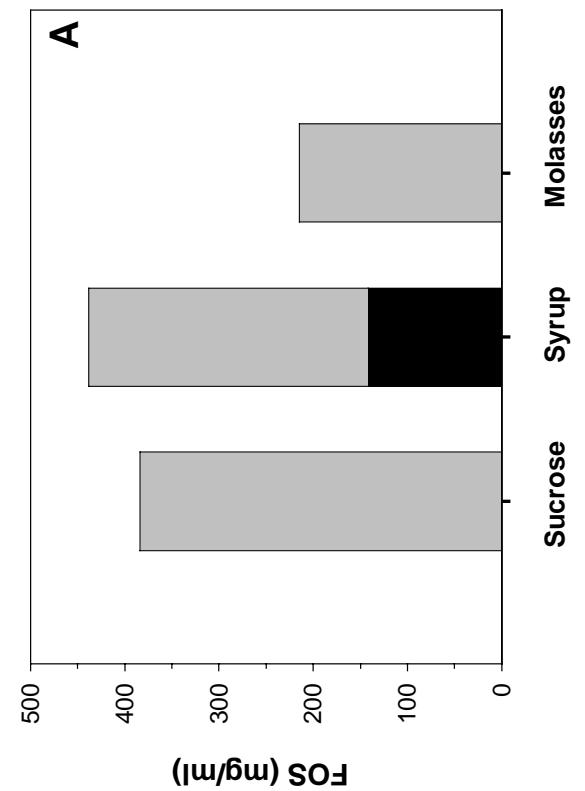

